The Lake breeze-ground-level Ozone Connection in Eastern Wisconsin: a Climatological Perspective

By: G. Jay Lennartson, Mark D. Schwartz

Lennartson GJ, Schwartz MD (2002). The Lake Breeze-Ground Level Ozone Connection in Eastern Wisconsin: A Climatological Perspective. Int. J. Climatol. 22: 1347-1364.

Made available courtesy of Wiley: http://dx.doi.org/10.1002/joc.802

***(C) Royal Meteorological Society. Reprinted with permission. No further reproduction is authorized without written permission from the Royal Meteorological Society \& Wiley. *** 


\title{
THE LAKE BREEZE-GROUND-LEVEL OZONE CONNECTION IN EASTERN WISCONSIN: A CLIMATOLOGICAL PERSPECTIVE
}

\author{
G. JAY LENNARTSON ${ }^{\mathrm{a}, *}$ and MARK D. SCHWARTZ ${ }^{\mathrm{b}}$ \\ a Department of Geography, University of North Carolina-Greensboro, Greensboro, NC 27402, USA \\ b Department of Geography, University of Wisconsin-Milwaukee, Milwaukee, WI 53201, USA \\ Received 20 June 2001 \\ Revised 3 April 2002 \\ Accepted 13 April 2002
}

\begin{abstract}
The Lake Michigan Air Quality Region (LMAQR) experiences exceedances of the $1 \mathrm{~h}$ health standard for ozone numerous times each summer. Previous short-term investigations have revealed that the lake breeze circulation is connected with very high levels of ozone in eastern Wisconsin (EWI). Findings from one of the more recent short-term research efforts have led to the development of a generalized conceptual model that details the role that the lake breeze circulation plays in transporting ozone-rich air of the Lake Michigan conduction layer onshore to EWI. Short-term studies, however, are limited by the small number of cases examined. To understand the ozone-lake breeze relationship from a climatological perspective, we analysed the spatial and temporal pattern of $1 \mathrm{~h}$ ozone exceedances in EWI during the months of May through to September, over the period 1985-99. Further, we used Laird et al.'s recently developed technique for discriminating lake breeze days to determine which exceedance-days over the period of our climatology occurred in association with lake breezes.

Our results show: (1) a decrease in both magnitude and frequency of exceedances of the 1 h ozone standard in EWI with increasing distance from the lakeshore; (2) a positive correlation between average onset time of the initial exceedance-hour and a site's distance from Lake Michigan; (3) a very high percentage of initial exceedance-hours occurring in association with southeasterly surface air flow; and (4) exceedances occurring in association with lake breezes $82.1 \%$ of the time at near-shore sites.

Collectively, our findings provide strong evidence that the lake breeze circulation is closely associated with the distribution of ozone in EWI in both space and time. Moreover, our results show that the lake breeze circulation is directly associated with a significant proportion of the exceedances of the $1 \mathrm{~h}$ ozone standard in EWI-particularly at near-shore sites. Thus, mandated reductions in regional-scale $\mathrm{NO}_{x}$ may be sufficient to allow 'inland' locations in EWI to meet the new $8 \mathrm{~h}, 80 \mathrm{ppb}$ Environmental Protection Agency health standard. However, further reductions in volatile organic compounds and $\mathrm{NO}_{x}$ within the major metropolitan centres of the LMAQR will likely be necessary if 'shoreline' locations in EWI are to meet the $1 \mathrm{~h}$ standard, and the stricter $8 \mathrm{~h}$ standard in the future. Copyright (C) 2002 Royal Meteorological Society.
\end{abstract}

KEY WORDS: Lake Michigan Air Quality Region; climatology; ground-level ozone; lake breeze; 1 h ozone standard; 8 h ozone standard

\section{INTRODUCTION}

\subsection{Air quality of the Lake Michigan Air Quality Region}

The Lake Michigan Air Quality Region (LMAQR; Figure 1) experiences exceedances of the $1 \mathrm{~h}, 120 \mathrm{ppb}$ standard for ozone on about 10-20 days per year (LADCO, 1995). Lying within the LMAQR, a six-county area of eastern Wisconsin (EWI; Figure 1) is one of only nine metropolitan areas in the USA with the federal government's 'severe' designation for ozone nonattainment (EPA, 1998a). Directly to the south, the

* Correspondence to: G. Jay Lennartson, University of North Carolina-Greensboro, Department of Geography, PO Box 26170, Greensboro, NC 27402-6170, USA; e-mail: gjlennar@uncg.edu 


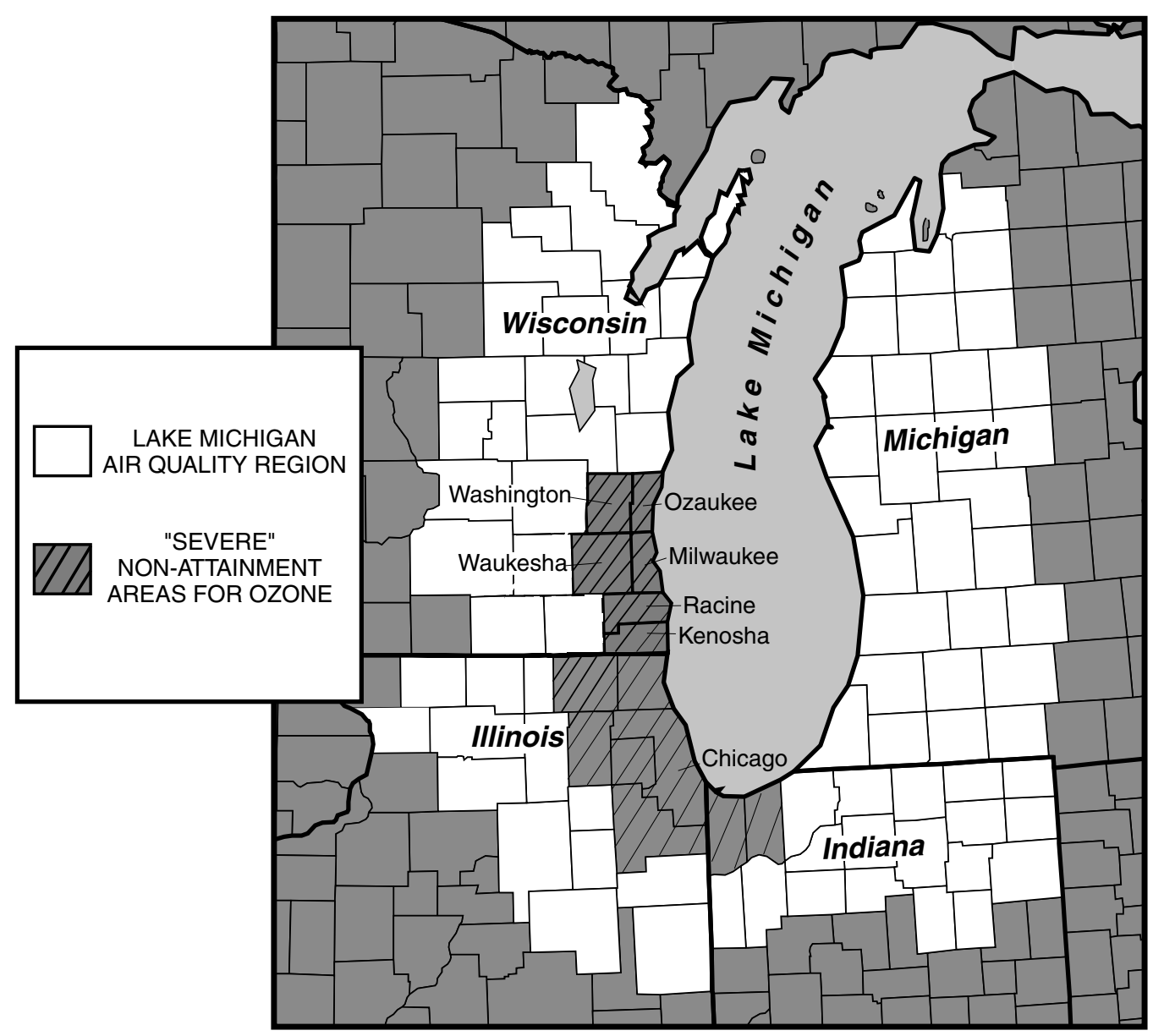

Figure 1. The LMAQR and its counties with the 'severe' designation for nonattainment of the $1 \mathrm{~h}$ health standard for ozone

Chicago-Gary-Lake County IL-IN area is another of the nine metropolitan areas with such a designation, and it too lies within the LMAQR.

Ozone exceedances are a cause of great concern because elevated levels of this oxidant are associated with harmful effects on human health, vegetation, and several man-made and natural materials (WI DNR 1997). High levels of ozone can cause headaches, dizziness, and impaired lung function (Cody et al., 1992). Several studies have shown a relationship between elevated levels of ozone and increased hospitalization (e.g. Burnett et al., 1997; Delfino et al., 1998).

\subsection{Ozone formation}

Ozone is a secondary pollutant formed through a series of photochemical reactions involving oxides of nitrogen $\left(\mathrm{NO}_{x}\right)$ and volatile organic compounds (VOCs) - ozone's precursors (LADCO, 1995). [See Seinfeld (1989) for a detailed discussion of the basic reactions and relationships among the pollutant species involved in the production and destruction of ozone.] Major sources of VOCs include: automobile emissions; crankcase emissions; gasoline and oil storage and transfer; incompletely burned coal or wood; and industrial use of paint solvents, degreasing agents, cleaning fluids, and ink solvents. Sources of $\mathrm{NO}_{x}$ include: fuel combustion in automobiles and power plants; and processes used in chemical plants (WI DNR, 1997).

The concentration of ozone in an area is a function of the rate, type, and sources of emissions, and the state of the atmosphere (Oke, 1987). Wind speed and direction, solar radiation, temperature, and mixing height 
are the meteorological conditions known to have the greatest influence on ozone concentrations (Lyons and Cole, 1976). On most summer days the precursor emissions are generally similar and, therefore, ozone levels are most strongly influenced by meteorological conditions (Haney et al., 1989). On the whole then, daily variations in ozone concentrations may be treated as largely a function of changing meteorological conditions (Comrie and Yarnal, 1992), which, themselves, are governed by the prevailing synoptic-scale circulation (e.g. cyclones and anticyclones) (McKendry, 1994).

\subsection{Ozone source areas and regional-scale transport}

EWI is a sink for emissions transported from source areas at the local, sub-regional, and regional scales (Lyons and Cole, 1976). At the local scale (i.e. greater Milwaukee), there are numerous sources of $\mathrm{NO}_{x}$ and VOCs (Lyons and Cole, 1976). Sub-regional-scale source areas include the urban and industrial areas of northern Indiana (i.e. Gary), northeastern Illinois (i.e. greater Chicago), and southeastern Wisconsin (Dye et al., 1995). On the synoptic (regional) scale, it has been known for over 20 years that very large $(2000 \mathrm{~km}$ diameter) volumes of air (i.e. air masses) in the eastern USA (EUS) can become universally polluted with ozone (henceforth referred to as 'air-mass' ozone). These ozone-rich air masses are generally associated with anticyclones that are moving very slowly across the EUS (Wolff et al., 1977; Altshuller, 1978; Vukovich and Fishman, 1986). Likely source areas of the ozone include the northeast metropolitan area, Detroit, St Louis, the Ohio River Valley, and parts of the southern USA (Lyons and Cole, 1976; Wolff et al., 1977; Hanna and Chang, 1995). Air parcels within these highly polluted air masses can be transported considerable distances (thousands of kilometres) over a time frame of several days (Lyons and Cole, 1976; Samson and Ragland, 1977).

Hanna and Chang (1995) found evidence for the association between slowly eastward moving anticyclones in the EUS and high levels of ozone at the regional scale; and, moreover, they were able to make a connection between air-mass ozone in the EUS and elevated ozone at the sub-regional scale — in particular, the LMAQR. Their findings were based on the analysis of four ozone exceedance episodes in EWI, which included measurements of ozone concentrations from aircraft flying along the southern (inflow) boundary of the LMAQR. They determined that during the high ozone events, polluted air with an ozone burden of 80 or $90 \mathrm{ppb}$ (just 30-40 ppb less than the $1 \mathrm{~h}$ standard) was advected into the LMAQR. Their analysis (by eye) of National Weather Service surface weather maps and US EPA surface ozone maps revealed that each of the events took place when a surface high-pressure system was situated over the EUS and a large ozone-laden air mass was located near the centre and to the west of the high. During the ozone episodes the LMAQR was thus subject to air flow with a southerly component and anticyclonic curvature, which brought polluted air into the LMAQR from the south and east.

The recent work of the Ozone Transport Assessment Group (OTAG) has further reinforced the connection between slow-moving anticyclones in the EUS and elevated ozone at the regional and sub-regional scales. OTAG's mission (from 1995 to 1997) was to evaluate the effects of the transport of ozone and its precursors on nonattainment areas in the EUS (Guinnup and Collum, 1997a). OTAG determined that most widespread regional-scale ozone episodes in the EUS are associated with slow-moving anticyclones that produce light winds, high temperatures, abundant insolation, and limited vertical mixing. They also determined that the clockwise circulation and eastward migration of the anticyclone is capable of transporting elevated ozone and precursors significant distances (Guinnup and Collum, 1997b). An important conclusion that can be drawn from OTAG's work (e.g. Husar and Renard 1997) is that elevated concentrations of ozone in the northern part of the OTAG domain (which includes the LMAQR) can result from the regional-scale transport of ozone generated from elsewhere within the OTAG domain.

\subsection{Sub-regional-scale transport: a conceptual model}

Thus, it is well established that ozone levels within the LMAQR can be elevated substantially when air-mass ozone is transported into the LMAQR via processes that operate on the regional scale. However, research (e.g. Lyons, 1972; Dye et al., 1995) would seem to indicate that regional-scale transport by itself is insufficient to 
explain the inordinately high ozone values often observed in the LMAQR - levels far higher than even the $1 \mathrm{~h}, 120 \mathrm{ppb}$ federal standard.

From similarities between two ozone episodes in the LMAQR, Dye et al. (1995) developed a generalized conceptual model of ozone formation and transport within the LMAQR that explains the exceptionally high levels of ozone that often occur in the near-shore environment of EWI. Key components of the conceptual model include: (1) an ozone-laden synoptic-scale high to the southeast of the LMAQR, which brings an ozone-polluted airstream to the LMAQR and generally elevates ozone levels throughout the region; (2) a land breeze or southerly to west-southwesterly offshore flow during the early morning hours, which transports early morning nocturnal boundary layer emissions from the Chicago-Gary and Milwaukee metropolitan areas into the stable air in the conduction layer ${ }^{1}$ over Lake Michigan - the strongly stable conduction layer over the lake limits vertical mixing and allows for the generation of high ozone concentrations within the conduction layer; (3) a less ozone-rich layer of air in the convective boundary layer (CBL) above the land because of convective mixing; and (4), the focus of attention in this study, a lake breeze circulation that brings the highly concentrated ozone of the conduction layer onshore to shoreline-located sites during the afternoon and early evening hours.

Dye et al.'s (1995) conceptual model is an important contribution to the understanding of ozone formation and transport within the LMAQR. It describes the known key mechanisms that link the regional (synoptic) and sub-regional scales during ozone episodes in EWI. Moreover, and of specific relevance to this paper, it connects the lake breeze circulation to instances when ozone levels exceed (sometimes far exceed) the $1 \mathrm{~h}$ ozone standard in EWI. Dye et al.'s (1995) conclusions, as well as those of other researchers who have studied ozone-lake breeze interactions in EWI (e.g. Lyons and Cole, 1976), are based on a limited number of cases, however. What has been lacking is an investigation of the ground-level ozone-lake breeze relationship in EWI over a longer time frame, i.e. from a climatological context: the objective of our investigation. Examination of the ozone-lake breeze relationship from a climatological perspective is particularly important, because federal air quality regulations consider multiple years of ozone observations when making ozone nonattainment area designations; and such a designation for a community carries with it considerable consequences.

\section{METHODS}

\subsection{Station and data selection}

As part of a synoptic climatology of surface-level ozone in EWI, Lennartson and Schwartz (1999) determined that the vast majority of the days that exceeded the $1 \mathrm{~h}$ ozone standard - during the period May-September 1985-88 and May-June 1989 - were consistent with the synoptic-scale aspects of Dye et al.'s (1995) conceptual model. To examine the ozone exceedance-lake breeze association in EWI - an important sub-regional-scale element of Dye et al.'s (1995) conceptual model - we analyse, here, the spatial and temporal pattern of $1 \mathrm{~h}$ ozone exceedances in EWI, during the months of May through to September, over the period 1985-99. Further, we applied a recently developed lake breeze identification technique over the period of our climatology to determine which exceedance-days in EWI occurred in association with a lake breeze. Such analyses will give us a better understanding of the significance of the lake breeze-ozone exceedance relationship in EWI.

For our analyses, we used $1 \mathrm{~h}$ average ozone and wind direction measurements from 13 WI DNR monitoring sites located throughout EWI (Table I and Figure 2). Because our interest is with very high values of $1 \mathrm{~h}$ ozone, and the $1 \mathrm{~h}$ health standard for ozone is set at $125 \mathrm{ppb}$ (after rounding), we included in our analysis only those values of $1 \mathrm{~h}$ ozone at the 13 sites that were greater than or equal to $125 \mathrm{ppb}$. The stations used in the climatology were chosen on the basis of their geographical representativeness of the study area, their proximities to Lake Michigan, and their length of record. Their respective proximities to the shoreline, ranged from a minimum distance of $1.1 \mathrm{~km}$, to a maximum distance of $72.9 \mathrm{~km}$ (Table I and Figure 2). Eight of the 13 stations were within $3 \mathrm{~km}$ of the Lake Michigan shoreline, and were referred to as 'near-shore' sites. The Alverno College, Appleton Avenue, and Waukesha sites were located $8.3 \mathrm{~km}, 10.8 \mathrm{~km}$, and $27.5 \mathrm{~km}$ respectively from the Lake Michigan shoreline, and were referred to as 'intermediate-distance' sites. All of 
Table I. Locations and AIRS numbers of Wisconsin Department of Natural Resources air quality and meteorological monitoring sites used in the study

\begin{tabular}{|c|c|c|c|c|c|}
\hline Location & AIRS \# & Site address & $\begin{array}{l}\text { Lat. } \\
\left({ }^{\circ} \mathrm{N}\right)\end{array}$ & $\begin{array}{l}\text { Lon. } \\
\left({ }^{\circ} \mathrm{W}\right)\end{array}$ & $\begin{array}{l}\text { Distance from Lake } \\
\text { Michigan }(\mathrm{km})\end{array}$ \\
\hline Kenosha $^{\mathrm{a}}$ & 550590002 & 7944 Sheridan Rd & 42.55 & 87.82 & 1.1 \\
\hline Bayside $^{b}$ & 550790085 & 601 E. Ellsworth Ln. & 43.17 & 87.90 & 1.2 \\
\hline Milwaukee-UWM-North ${ }^{\mathrm{a}}$ & 550790041 & 2114 E. Kenwood Blvd & 43.07 & 87.88 & 1.4 \\
\hline Racine $^{\mathrm{a}}$ & 551010017 & 1519 Washington Ave. & 42.70 & 87.78 & 1.4 \\
\hline Manitowoc ${ }^{b}$ & 550710002 & 2103 Division St. & 44.07 & 87.67 & 1.4 \\
\hline Kewaunee $^{b}$ & 550610001 & 911 Third St. & 44.45 & 87.52 & 1.5 \\
\hline South Milwaukee ${ }^{b}$ & 550791025 & 3501 Blakewood Ave. & 42.88 & 87.87 & 2.3 \\
\hline Grafton $^{\mathrm{a}}$ & 550890005 & Grafton High School & 43.32 & 87.94 & 3.0 \\
\hline Milwaukee-Alverno College ${ }^{\mathrm{a}}$ & 550790048 & 3401 S. 39th St. & 42.97 & 87.95 & 8.3 \\
\hline Milwaukee-Appleton Avenue & 550790044 & 7528 W. Appleton Ave. & 43.08 & 88.00 & 10.8 \\
\hline Waukesha $^{a}$ & 551330017 & 225 N. Grand Ave., Carroll College & 43.00 & 88.22 & 27.5 \\
\hline Oshkosh $^{\mathrm{b}}$ & 551390007 & 725 Butler Ave. & 44.07 & 88.52 & 67.7 \\
\hline Appleton $^{\mathrm{a}}$ & 550870010 & 4321 N. Ballard Rd & 44.30 & 88.38 & 72.9 \\
\hline
\end{tabular}

${ }^{a}$ The monitoring site provided ozone data for the investigation.

$\mathrm{b}$ The monitoring site provided both ozone and wind direction data for the investigation.

the near-shore and intermediate-distance sites were within range of the lake breeze circulation - which can reach more than $30 \mathrm{~km}$ inland (Hewson and Olsson, 1967), but no more than $50 \mathrm{~km}$ at most (Lyons and Cole, 1976). The Waukesha site, at a distance of nearly $30 \mathrm{~km}$ from the shoreline, is located near the outer limits of the range of the EWI lake breeze circulation. The Oshkosh and Appleton stations, at distances of $67.7 \mathrm{~km}$ and $72.9 \mathrm{~km}$ respectively from Lake Michigan, were located far enough inland so as to be well out of the range of the lake breeze circulation.

\subsection{Methods used to analyse the frequency, magnitude, temporal pattern, and association with southeasterly flow of 1 h exceedances in EWI}

On the basis of the conceptual model, exceedances of the $1 \mathrm{~h}$ ozone standard should occur with a greater frequency at sites located very near to the shoreline, and the frequency should decrease as the distance from the shore increases. Additionally, and also based on Dye et al.'s (1995) model, a similar trend in the observed magnitude of $1 \mathrm{~h}$ exceedances in EWI should be observed, i.e. the magnitude of 1 hour exceedances should be greater at the near-shore sites and smaller at the sites located farther from the shoreline.

To examine the spatial distribution of the frequency and magnitude of $1 \mathrm{~h}$ exceedances in EWI, we: (1) calculated the total number of days with one or more hours of $1 \mathrm{~h}$ ozone greater than or equal to $125 \mathrm{ppb}$ (such days are henceforth referred to as 'exceedance-days'); (2) determined the total number of hours that $1 \mathrm{~h}$ ozone was greater than or equal to $125 \mathrm{ppb}$ (such hours are subsequently referred to as "exceedancehours'); (3) calculated the average of all the $1 \mathrm{~h}$ ozone values that were greater than or equal to $125 \mathrm{ppb}$; and (4) identified the highest $1 \mathrm{~h}$ value of ozone. We made these calculations for each of the 13 ozone monitoring stations in EWI over the 15 year period of our climatology.

To examine further the ozone-lake breeze association in EWI, we also analysed the temporal pattern of $1 \mathrm{~h}$ ozone exceedances in EWI. We hypothesized (on the basis of the conceptual model) that, as the leading edge of the ozone-laden conduction layer (i.e. the lake breeze front) pushes inland with time during the day, the sites located closest to the lake should have their first $1 \mathrm{~h}$ exceedances at an earlier hour in the day than the sites located farther inland. To examine this hypothesis from a climatological perspective, we calculated the average hour when $1 \mathrm{~h}$ ozone first exceeded $124 \mathrm{ppb}$ during the period of our climatology and at 11 of the ozone monitoring sites in EWI. We did not include the Appleton and Oshkosh stations in our analysis, because they are located far enough inland so as to be beyond the range of the lake breeze circulation. 


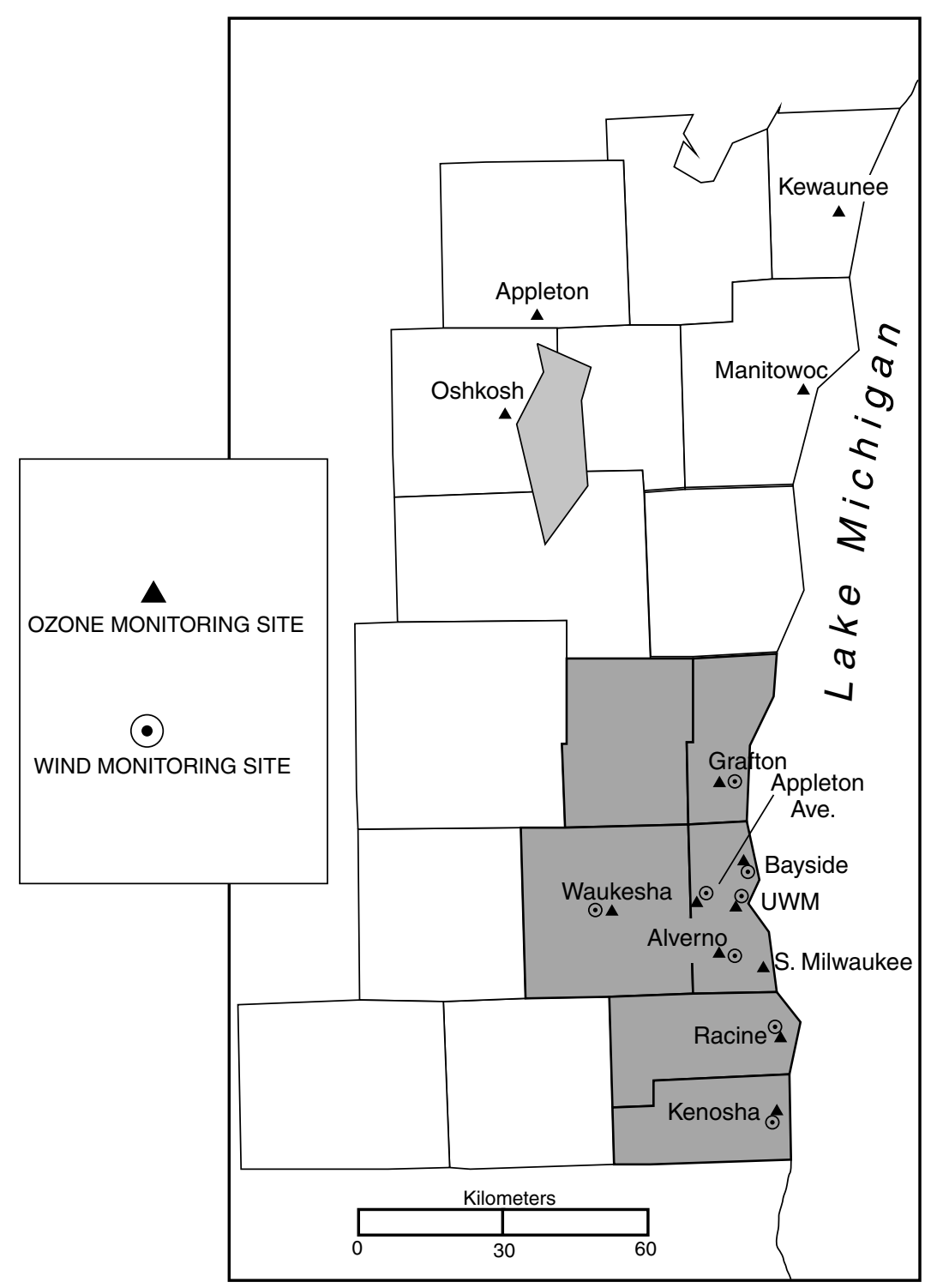

Figure 2. Wisconsin Department of Natural Resources air quality and meteorological monitoring stations

An important finding from Dye et al.'s (1995) case study, which later became a seminal component of their conceptual model, was their connection between very high levels of ozone at lakeside monitoring sites in EWI, and a southeasterly lake breeze circulation along the western shoreline of Lake Michigan. To examine this relationship from a climatological perspective, we calculated the percentage of days where the initial exceedance-hour of an exceedance-day occurred in association with a $1 \mathrm{~h}$ average wind between 91 and $179^{\circ}$ (i.e. southeasterly flow). Eight monitoring sites in EWI (Figure 2), where both hourly wind and ozone data were monitored throughout the period of our climatology, were used in this analysis. Inherent in the analysis is the implication that the ozone detected at the monitoring stations was delivered to the site by the onshore, southeasterly flow of the thermally direct lake breeze circulation. We chose the southeasterly wind direction because lake breezes in EWI are predominantly from the southeast (Williams, 1985). Further, Dye et al. (1995), as part of their case study, noted an increase in ozone concentration at sites in EWI when the winds shifted to the southeast with the passage of the lake breeze front. 


\subsection{Method for identifying lake breezes on exceedance-days}

The above methods allow us to make inferences about the ozone exceedance-lake breeze association based on observed spatial and temporal patterns of ozone in EWI. Further insight into the role and significance of the lake breeze circulation on $1 \mathrm{~h}$ exceedances in EWI can be gained by knowing which and how many exceedance-days in EWI occurred in association with lake breezes. Laird et al. (2001) provide a methodology that we will employ to accomplish this objective. Their method is comprised of four criteria that were used to identify lake breezes along the Lake Michigan shoreline at Milwaukee, Wisconsin (MKE), Muskegon, Michigan (MKG), and Chicago O'Hare Airport, Illinois (ORD) over the time period 1982-1996. Lake breezes were identified during this period to develop a climatology of Lake Michigan lake breezes. The authors used data from their lake breeze climatology to generate composites of sea-level pressure (SLP) and $10 \mathrm{~m}$ winds on days in which lake breezes occurred on Lake Michigan's east shore (ES), west shore (WS), and on both shores (BS). Comparison with observed records of lake breeze events during the summers of 1996-97 revealed that their method 'reasonably identified Lake Michigan lake breeze events' (Laird et al., 2001: 409). Moreover, Laird et al.'s (2001) method was better able than previously developed methods (i.e. Biggs and Graves, 1962: Lyons, 1972) to distinguish non-lake breeze events. Laird et al.'s (2001: 412) four criteria for identifying lake breezes are as follows:

(1) A change in average wind direction from offshore or calm conditions in the morning (0500-0700 LST) to onshore during the afternoon (1600-1800 LST). Onshore and offshore flows were defined using a north-south coastline orientation. Any wind within the range $181-359^{\circ}$ was interpreted as offshore flow; and any wind within the range $1-179^{\circ}$ degrees was considered onshore flow.

(2) A positive difference in temperature between the daily maximum at an inland station and the lake surface measured at the same hour.

(3) An average air temperature in the morning (0500-0700 LST) lower than during the afternoon (1600-1800 LST).

(4) An average wind speed in the morning (0500-0700 LST) less than $5.5 \mathrm{~m} \mathrm{~s}^{-1}$.

Criteria (1) and (2) were used to identify the passage of a lake breeze, criteria (3) and (4) were designed to exclude other atmospheric phenomena, in particular synoptic-scale fronts (Laird et al., 2001).

We applied these four criteria to exceedance-days at the eight WI DNR sites (Figure 2) in EWI that monitored both wind and ozone (and surface air temperature) throughout the 15 year period of our climatology. This was done to determine whether lake breezes occurred on those days. With respect to criterion (2), we used Madison, WI (MSN), as our inland station (located $\sim 130 \mathrm{~km}$ inland), and the Southern Lake Michigan Data Buoy (45007) for our lake surface temperature readings. We found it necessary to modify criterion (2) because our database of daily maximum temperatures for Madison did not include the hour at which the daily maximum temperature occurred. We determined that a reasonable solution to this problem was to use a $24 \mathrm{~h}$ average lake surface temperature in place of the $1 \mathrm{~h}$ reading originally called for. To make certain that there was not too much variation in the hourly lake surface temperature measurements on exceedance-days (which would render our methodology incorrect), we computed the standard deviations of the hourly temperatures. In all cases the standard deviations were quite small, indicating that the means were representative of lake surface temperatures on exceedance-days, and could therefore be used along with the daily maximum temperature at Madison when determining whether or not criterion (2) was met.

\subsection{Compositing methods}

Since a lake breeze circulation cannot occur in EWI unless synoptic-scale conditions are appropriate, it is important to examine the average synoptic-scale condition on exceedance-days to see if the synopticscale setting, climatologically speaking, is conducive to lake breeze formation. For the final phase of our investigation then, we generated synoptic-scale composite maps of SLP and $500 \mathrm{hPa}$ heights. The daily, 12 UTC SLP and $500 \mathrm{hPa}$ height data for our composites came from the National Meteorological Center's (NMC) 'Grid Point CDROM: Version III' (NCAR, 1996). A day's 12 UTC SLP and height data was included 
in our composites if any one of the 13 ozone monitoring stations (Table I and Figure 2) in EWI reported one or more hours with an ozone reading greater than or equal to $125 \mathrm{ppb}-$ for the period May-September 1985-94. Once completed, our exceedance-day composite of SLP was compared with Laird et al.'s (2001) SLP composites of lake breeze events.

Since it is possible for composites to be comprised of dissimilar atmospheric patterns, and thus yield a false impression of the typical pattern associated with a given environmental phenomenon, Yarnal (1993) recommends calculating standard deviations when generating composites. Therefore, we calculated a 'mean standard deviation' for both of our composites. To accomplish this, we computed a standard deviation (for each individual gridpoint) using the 12 UTC grids that comprised the respective SLP and $500 \mathrm{hPa}$ height composites. This step resulted in a grid of standard deviations for our SLP composite and a similar grid for our $500 \mathrm{hPa}$ height composite. To summarize each of the grids, we calculated each grid's mean standard deviation. For comparison with these means, we used the same technique, but applied it to the entire population of daily 12 UTC grids of SLP and $500 \mathrm{hPa}$ height data spanning the time period 10 May 1985-18 June 1994, the time period from which the grids comprising our composites were drawn.

In what follows, we present the results of our climatology of ground-level ozone in EWI. The abovedescribed analysis methods are designed to provide insight into the significance, in climatological terms, of the lake breeze-ground-level ozone association in EWI.

\section{RESULTS AND DISCUSSION}

\subsection{Frequency of 1 h exceedances in EWI}

Figure 3(a) and (b) show scaled-symbol maps of, respectively: (1) the total number of days with one or more hours of hourly ozone greater than or equal to $125 \mathrm{ppb}$ (i.e., exceedance-days); and (2) the total number of hours with $1 \mathrm{~h}$ ozone greater than or equal to $125 \mathrm{ppb}$ (i.e., exceedance-hours). In essence, Figure 3(a) and (b) show the frequency of extreme ozone events in EWI. Examination of the pattern of scaled-symbols in Figure 3(a) and (b) reveals that both the number of exceedance-days and exceedance-hours show a clear trend of decreasing value with increasing distance from the Lake Michigan shoreline: the highest values for each parameter are found at monitoring stations located within $3 \mathrm{~km}$ of the shoreline. At the three sites situated at intermediate distances from the lake (Waukesha, Appleton Avenue, and Alverno College), a marked decrease in the number of exceedance-days and exceedance-hours is observed; and at the two sites located well away from the lake, the Appleton and Oshkosh sites, significantly smaller values of each parameter are shown.

At Kewaunee, located just $1.5 \mathrm{~km}$ from the shoreline, the number of exceedance-days and exceedance-hours is smaller than that observed at the other near-shore sites. However, this can be explained by Kewaunee's greater distance from the Milwaukee and Chicago source areas compared to that of the other near-shore monitoring sites in EWI. The greater distance between Kewaunee and source areas to the south would provide opportunities for increased dilution in the conduction layer, which would result in lower ozone concentrations reaching the more northerly located Kewaunee site; hence, one would expect fewer exceedance-days and hours at the Kewaunee site than found at the other near-shore sites.

The trend shown in Figure 3, of a decrease in frequency of extreme ozone events with an increase in distance from the shoreline, makes sense if one considers the well-established fact that the lake breeze itself exhibits a behaviour of decreasing frequency with increasing distance from the shore. This fact, coupled with the known relationship between the inland movement of the lake breeze and elevated amounts of ground-level ozone (see Lyons, 1972; Lyons and Cole 1973, 1976; Dye et al., 1995), thus strongly connects the lake breeze, climatologically, with exceedances of the $1 \mathrm{~h}$ ozone standard in EWI.

\subsection{Magnitude of 1 h exceedances in EWI}

Figure 4 conveys information regarding the spatial distribution of the magnitude of extreme ozone events in EWI. Figure 4(a) is a scaled-symbol map showing each site's average of all its $1 \mathrm{~h}$ ozone readings that were 
(a)

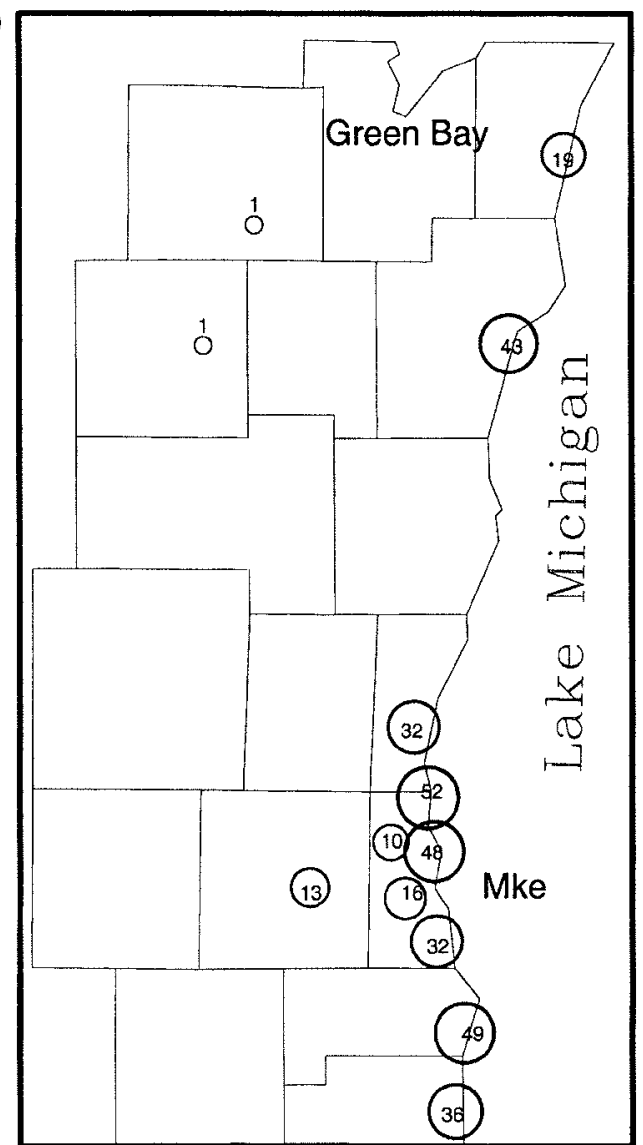

(b)

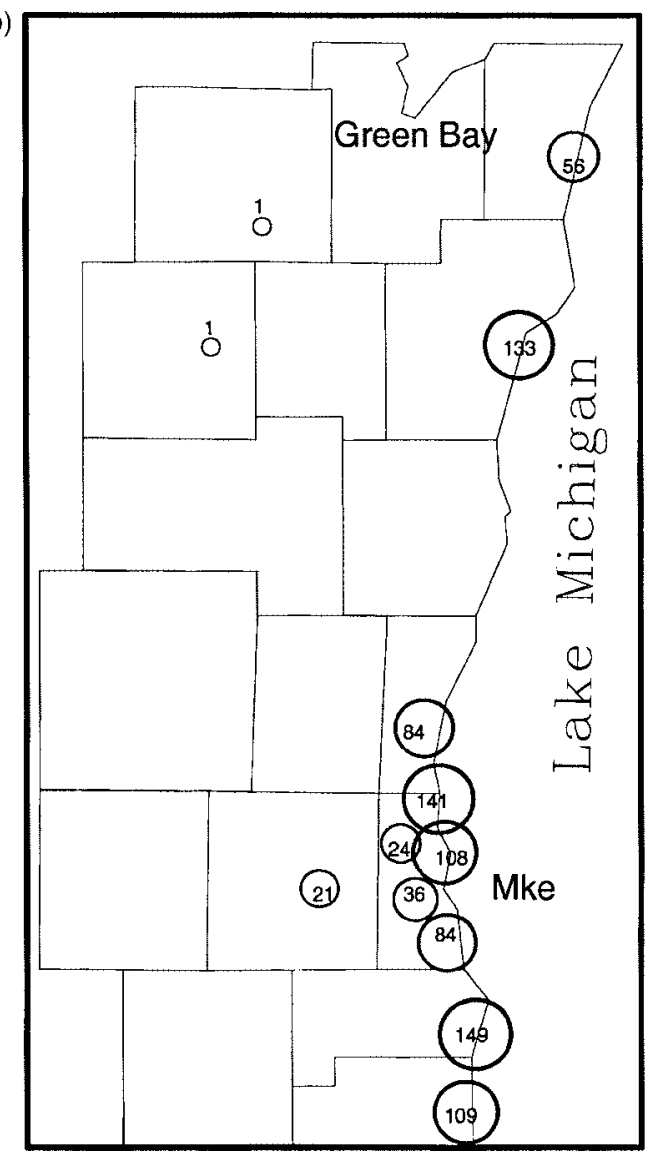

Figure 3. Scaled symbol-maps with data values of: (a) the number of days with one or more hours of 1-h ozone greater than or equal to $125 \mathrm{ppb}$, and (b) the total number of hours that $1 \mathrm{~h}$ ozone was greater than or equal to $125 \mathrm{ppb}$

greater than or equal to $125 \mathrm{ppb}$ over the 15 year period of our climatology. Figure 4(b) shows a scaled-symbol map of the highest values of $1 \mathrm{~h}$ ozone measured at each site during the course of the climatology.

The averages shown in Figure 4(a) tend to be similar across sites located at both close and intermediate distances from the lake. Alverno College, located at the intermediate distance of $8.3 \mathrm{~km}$ from the shoreline, actually exhibits the highest average; however, its value is only marginally greater than that of any of the near-shore sites. The averages do not decrease significantly until Waukesha, located nearly $30 \mathrm{~km}$ from the shoreline. The similarity in values between the near-shore and intermediate-distance sites is to be expected, since very little mixing, and hence very little dilution of the ozone contained within the conduction layer, would occur as the lake breeze travelled its first few kilometres inland from the shoreline. These findings are consistent with those of Lyons and Olsson (1972) and Lyons and Cole (1976), who determined that it was not until after about $10 \mathrm{~km}$ inland fetch that mixing in the thermal internal boundary layer (TIBL) would reach sufficient heights to fumigate air from the upper levels of the inflow layer. Dye et al. (1995), based on the work of Lyons and Cole (1976), as well as observations from their own case study, determined that the upper levels of the inflow layer contained lower concentrations of ozone; thus, when the inland thickening TIBL eventually impinged the aloft layers of the onshore flow, air with a lesser ozoner burden was mixed-down to the surface at the more inland-located sites - which agrees nicely with the lower values shown in Figure 4(a) at our sites west of Alverno College and Appleton Avenue.

As with the frequency of exceedance-days and exceedance-hours at the Kewaunee site (Figure 3), Kewaunee's average of the $1 \mathrm{~h}$ ozone greater than or equal to $125 \mathrm{ppb}$ (Figure 4(a)) is smaller than 
(a)

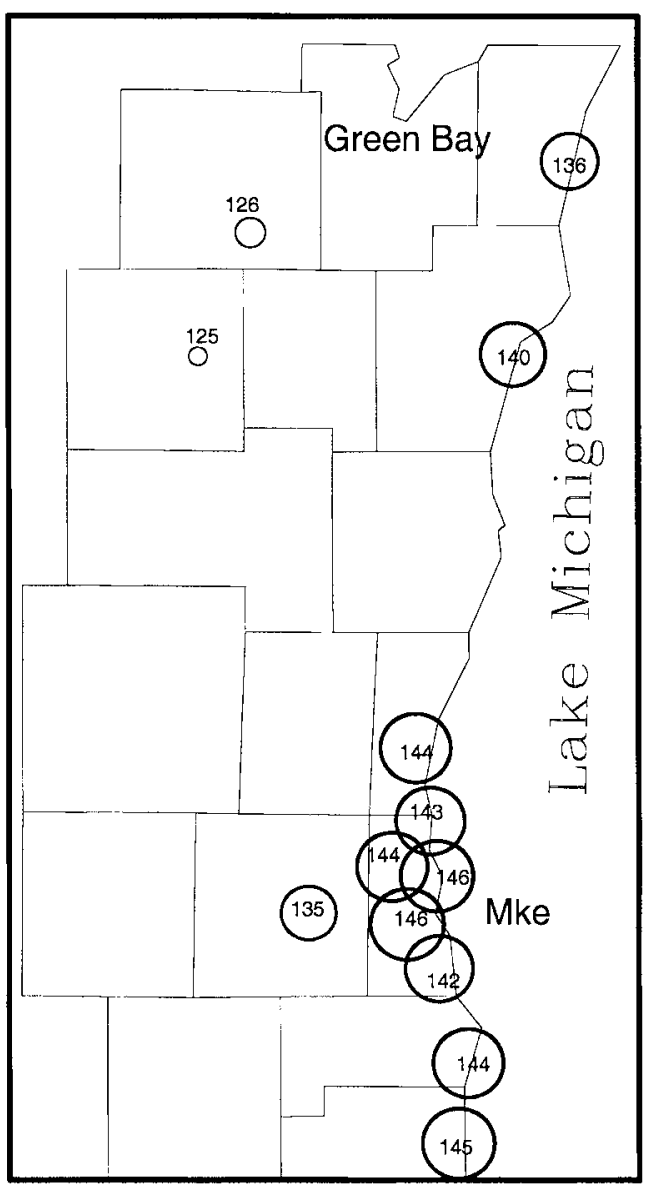

(b)

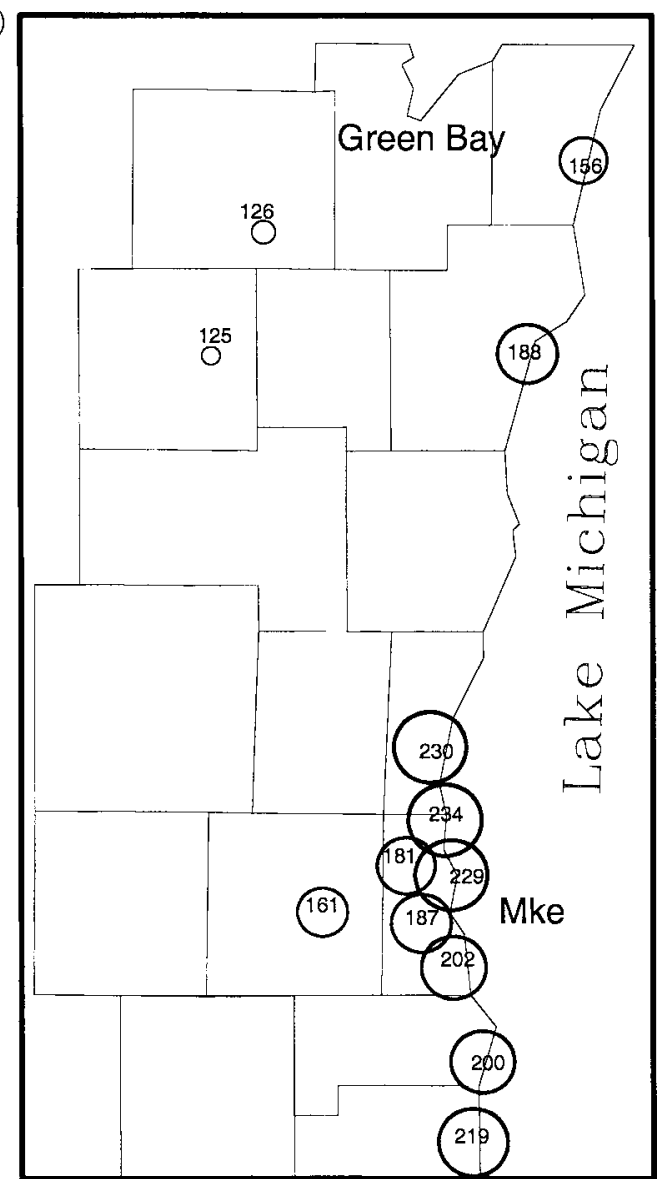

Figure 4. Scaled symbol-maps with data values of (a) the average of the $1 \mathrm{~h}$ ozone values greater than or equal to $125 \mathrm{ppb}$, and (b) the highest value of 1-hour ozone (units are ppb)

that found at the other near-shore sites in EWI; and here too, the anomaly can be explained by Kewaunee's greater distance from the ozone and precursor-rich source areas of Greater Milwaukee and Chicago.

Figure 4(b) shows scaled-symbol plots of the highest $1 \mathrm{~h}$ ozone measurements at each of the 13 monitoring sites for the period of our climatology. This expression of the spatial distribution of the climatological magnitude of $1 \mathrm{~h}$ exceedances in EWI, like that shown in Figure 4(a), shows a strong trend of decreasing value in the size of the highest value of $1 \mathrm{~h}$ ozone with increasing distance from the shore. This is what we would expect, given that the air with the highest ozone concentrations, the air residing in the lowest $300 \mathrm{~m}$ of the atmosphere over the lake (i.e. the air within the conduction layer), would be first mixed-down to the ground at the sites lying nearest to the shoreline - which is what Dye et al. (1995) observed in their case study, and incorporated into their conceptual model.

Kewaunee's highest value of $1 \mathrm{~h}$ ozone is smaller than that found at the other near-shore sites, and the intermediate-distance sites as well; and once again, the inconsistency is most likely a reflection of Kewaunee's more northerly location along the Lake Michigan shoreline, which results in greater transport distances for ozone and precursors generated in the Milwaukee and Chicago metropolitan areas.

Thus, our analysis in EWI reveals a trend of decreasing frequency and magnitude of extreme ozone events with increasing distance from Lake Michigan. This finding is reinforced when data from the 13 stations are used to compute product-moment correlation coefficients for 'station distance from Lake Michigan', and the number of exceedance-days, the number of exceedance-hours, the average of the $1 \mathrm{~h}$ ozone values greater 
Table II. Product-moment correlations for 'distance from the Lake Michigan shoreline' and each of the respective parameters below

\begin{tabular}{lccc}
\hline Parameter & $\begin{array}{c}\text { Correlation } \\
\text { coefficient }\end{array}$ & Significance & $\begin{array}{c}\text { No. of } \\
\text { samples }\end{array}$ \\
\hline $\begin{array}{l}\text { Number of days that, on one or more hours, } \\
1 \text { h ozone was } \geq 125 \mathrm{ppb}\end{array}$ & -0.756 & 0.005 & 13 \\
$\begin{array}{l}\text { Total number of hours that 1 h ozone was } \\
\geq 125 \mathrm{ppb}\end{array}$ & -0.737 & 0.005 & 13 \\
$\begin{array}{l}\text { Average of } 1 \text { h ozone } \geq 125 \mathrm{ppb} \\
\text { Highest value of 1 h ozone }\end{array}$ & -0.902 & 0.005 & 13 \\
$\begin{array}{l}\text { Average hour of the first time 1 h ozone is } \\
\text { exceeded }- \text { for those days with 1 h ozone } \\
\text { values } \geq 125 \text { ppb }\end{array}$ & -0.817 & 0.005 & 13 \\
\end{tabular}

than or equal to $125 \mathrm{ppb}$, and the highest value of $1 \mathrm{~h}$ ozone. Our computations show that each of the four variables is strongly, inversely correlated with station distance to the lakeshore (Table II).

These results are important because they are consistent with Dye et al.'s (1995) findings from their case study, which revealed that ozone levels were highest along the Lake Michigan shoreline, and then decreased with increasing distance from the shore; and further, our results are precisely what their conceptual model predicts, i.e. the monitoring sites with the highest ozone levels and the greatest frequency of extreme ozone events are those located very near to the Lake Michigan shoreline. Moreover, these findings show that, in a climatological context, the lake breeze strongly influences the magnitude and frequency of exceedances of the $1 \mathrm{~h}$ standard in EWI, as well as the spatial distribution of those exceedances.

\subsection{Temporal pattern of $1 \mathrm{~h}$ exceedances in EWI}

Figure 5 provides a scaled-symbol map of the average hour when $1 \mathrm{~h}$ ozone first exceeded $124 \mathrm{ppb}$ at each of the 11 monitoring sites used for this component of our study. (As mentioned earlier, we chose not to include the Appleton and Oshkosh sites in our analysis because they were located beyond the range of the lake breeze circulation.) Figure 5 shows that Kenosha, the station closest to the lakeshore, has, on average, its first exceedance at approximately $1300 \mathrm{CDT}$, whereas Appleton Avenue, Alverno College, and Waukesa (sites at intermediate distances from the lake) have their first exceedances $1.5-2.5 \mathrm{~h}$ later in the day. Kewaunee and Manitowoc, which are both located very near the Lake Michigan shore, have later average initial exceedance times than the other near-lakeshore monitoring sites. Their respective later average initial-exceedance onset times, as was the case with the previously mentioned anomalies at the Kewaunee site, likely result from the fact that Kewaunee and Manitowoc are located farther north along the Lake Michigan shoreline, which increases the time it takes to transport ozone and its precursors northward from emission source areas in the Chicago and Milwaukee metropolitan areas. With the exception of the Kewaunee and Manitowoc stations then, Figure 5 shows a distinct trend of a later average initial-exceedance onset time with increasing distance from the shoreline.

To test the strength of the relationship between increased distance from the lakeshore and average onset time of the initial exceedance-hour, we computed product-moment correlations between the two variables, using data from the 11 monitoring sites shown in Figure 5. An examination of Table II reveals that the average onset time of the initial exceedance-hour is strongly positively correlated with distance from the lakeshore. This result agrees well with the scaled-symbol map (Figure 5), which shows that the average onset times of the initial exceedance-hour occur later in the day at the inland-located sites than at the near-shore sites.

Since it is well established, on a case-by-case basis (e.g. Lyons and Cole 1976; Dye et al., 1995), that the inland progression of the lake breeze can result in significant increases in ozone at sites experiencing passage of the lake breeze front, then it stands to reason that it is the inland movement of the lake breeze that is 


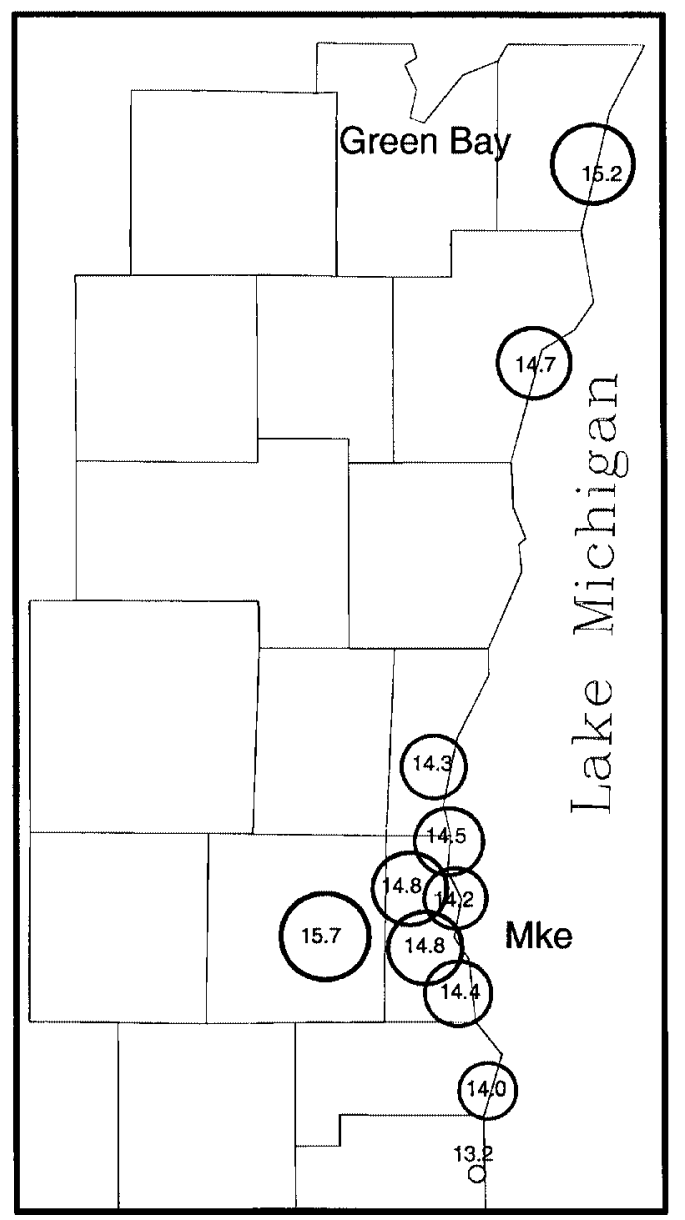

Figure 5. Scaled symbol-map with data values of the average initial exceedance-hour

responsible for our (above) findings that show a trend of later average onset times of the initial exceedancehour with increasing distance from Lake Michigan. Thus, we have provided further evidence for the close association between the lake breeze circulation and exceedances of the $1 \mathrm{~h}$ ozone standard in EWI. Moreover, these findings agree with the component of Dye et al.'s (1995) conceptual model that explains how the highly concentrated ozone of the conduction layer is brought onshore by the lake breeze circulation, resulting in exceedances at near-shore sites first.

\subsection{Initial exceedance-hours and wind direction}

Our analysis of the percentage of days where the initial exceedance-hour of an exceedance-day occurred in association with southeasterly flow revealed that Kenosha, located $1.1 \mathrm{~km}$ from the shoreline (Table I), had $100 \%$ of its initial exceedance-hours of exceedance-days occurring in association with southeasterly flow. In contrast, the Appleton Avenue monitoring site, located $10.8 \mathrm{~km}$ from Lake Michigan, had the lowest percentage $(80 \%)$ of exceedance-days with initial exceedance-hours occurring in conjunction with southeasterly flow. Nevertheless, $80 \%$ is still a remarkably high percentage. The remaining six sites exhibited percentages ranging from the mid-80s to the upper-90s (Table III). The average of the eight sites was $91 \%$. Such high percentages of exceedance-days with initial exceedance-hours occurring in association with southeasterly flow are significant, because they suggest that the exceedances at all eight sites were closely tied to the onshore component of the lake breeze circulation. Furthermore, since the eight sites were geographically 
representative of locations that the lake breeze frequents in EWI, it allows us to make the generalization that exceedances of the $1 \mathrm{~h}$ standard in EWI are closely connected with the inland movement of the lake breeze circulation.

\subsection{Identifying lake breezes on exceedance-days}

By applying Laird et al.'s (2001) criteria to exceedance-days at each of eight WI DNR stations, we were able to determine the percentage of exceedance-days that occurred in association with a lake breeze. As shown in Table III, each of the near-shore sites (those within $3 \mathrm{~km}$ of the lakeshore: Kenosha, UWMN, Bayside, Racine, Grafton) had a high percentage of their exceedance-days occurring in association with a lake breeze circulation (the average of the near-shore sites was a rather high $82.1 \%$ ). The sites located a bit farther inland from the lakeshore (the intermediate-distance stations: Alverno, Appleton Avenue, Waukesha), had a smaller percentage of their exceedance-days occurring in association with lake breezes. Their mean was just $58.3 \%$. Nevertheless, at each of the three intermediate-distance sites, more than half of the exceedance-days experienced a lake breeze circulation. Keeping Dye et al.'s (1995) conceptual model in mind, these results imply that the lake breeze circulation was directly connected with the exceedances that occurred at the sites. The higher percentages of exceedance-days with lake breezes at the near-shore sites versus the intermediatedistance sites implies that the lake breeze plays a more significant role in $1 \mathrm{~h}$ exceedances at the former than it does at the latter; or it may be that Laird et al.'s (2001) stringent criteria for identifying lake breezes is better at identifying them at the near-shore sites than at the intermediate-distance sites.

We also applied Laird et al.'s (2001) lake breeze identification methodology to the above-mentioned (see Section 3.4) days where the initial exceedance-hour of an exceedance-day occurred in association with southeasterly flow. This was done because it is possible that the observed southeasterly flow resulted not from a lake breeze, but instead was a reflection of the prevailing southeasterly synoptic-scale flow. Table III shows the percentages of the days having an initial exceedance-hour with southeasterly flow that occurred in association with a lake breeze. As with the percentage of exceedance-days meeting Laird et al.'s (2001) four criteria, the highest values are found at the near-shore sites, with lower percentages occurring at the intermediate-distance stations. With the exception of Alverno and Waukesha, on three-quarters or more of the exceedance-days where the initial exceedance-hour occurred in association with southeasterly flow, the southeasterly flow could be attributed to a lake breeze circulation. Therefore, our use in Section 3.4 of

Table III. For each of eight WI DNR sites: the percentage of exceedance-days having an initial exceedance-hour occurring in association with a $1 \mathrm{~h}$ average wind between 91 and $179^{\circ}$; the percentage of exceedance-days that met Laird et al.'s (2001) criteria for determining whether a lake breeze occurred; and the percentage of initial-hour SE flow exceedance-days ${ }^{\mathrm{a}}$ that met Laird et al.'s (2001) criteria for determining whether a lake breeze occurred

\begin{tabular}{lcccc}
\hline WI DNR site & $\begin{array}{c}\text { Distance from } \\
\text { Lake Michigan } \\
(\mathrm{km})\end{array}$ & $\begin{array}{c}\text { Exceedance-Days with } \\
\text { an initial } \\
\text { exceedance-hour } \\
\text { occurring in association } \\
\text { with SE flow (\%) }\end{array}$ & $\begin{array}{c}\text { Exceedance-days } \\
\text { meeting Laird } \text { et al.'s } \\
(2001) \text { four criteria } \\
(\%)\end{array}$ & $\begin{array}{c}\text { Initial-hour SE flow } \\
\text { exceedance-days } \\
\text { Meeting Laird } \text { et al.'s } \\
\text { (2001) four criteria } \\
(\%)\end{array}$ \\
\hline Kenosha & 1.1 & 100 & 82.8 & 82.8 \\
Bayside & 1.2 & 87.2 & 72.3 & 75.6 \\
UWMN & 1.4 & 97.8 & 81.8 & 80.0 \\
Racine & 1.4 & 97.9 & 86.4 & 78.7 \\
Grafton & 3.0 & 96.9 & 87.1 & 83.9 \\
Alverno & 8.3 & 86.7 & 53.3 & 46.2 \\
Appleton Ave. & 10.8 & 80.0 & 60.0 & 75.0 \\
Waukesha & 27.5 & 84.6 & 61.5 & 63.6
\end{tabular}

a An 'initial-hour SE flow exceedance-day' is a day where the initial exceedance-hour on an exceedance-day occurred in association with a $1 \mathrm{~h}$ average wind between 91 and $179^{\circ}$ (southeasterly flow). 
instances where the initial exceedance-hour occurred in association with a southeasterly flow as a proxy for evidence of a lake breeze appears justified.

\subsection{Average synoptic-scale conditions on exceedance-days}

The various analysis techniques employed thus far reveal a pattern of $1 \mathrm{~h}$ exceedances in EWI (in both space and time) that strongly implies that, in the climatological context, there is a close association between the lake breeze and exceedances of the $1 \mathrm{~h}$ ozone standard in EWI. To reinforce this association further, we examined the average synoptic-scale condition on exceedance-days to determine if the synoptic-scale setting on exceedance-days was conducive to lake breeze formation. Figure 6 shows the synoptic-scale composite maps of SLP and $500 \mathrm{hPa}$ heights that we generated to accomplish our goal.

To make certain that our composites are not averages of dissimilar synoptic patterns (Yarnal, 1993), we calculated their respective mean standard deviations. Figure 7 reveals that the mean standard deviations of the SLP and $500 \mathrm{hPa}$ composites are relatively small, particularly when compared with the mean standard deviations calculated using the population of 12 UTC grids (Figure 7). This indicates that there is a relatively small amount of variation in the grids that comprise the SLP and $500 \mathrm{hPa}$ composites, giving us confidence that our composites do represent the typical situation associated with exceedance-days in EWI.

The dominant feature of our SLP composite (Figure 6(a)) is a large and expansive anticyclone situated to the southeast of the LMAQR. The anticyclone is centred over the eastern edge of the Ohio River Valley, but dominates the Mid-Atlantic and southeast regions of the USA as well. The geographic location of the anticyclone relative to EWI, along with the weak pressure gradient on its western edge, would establish a weak southwesterly synoptic-scale surface flow across EWI. Such a flow in association with a land breeze could transport ozone's precursors offshore into the Lake Michigan conduction layer during the early morning hours; then, following the development of a southeasterly lake breeze circulation, the concentrated ozone within the conduction layer could be transported onshore to areas in EWI later in the day.

Our $500 \mathrm{hPa}$ composite (Figure 6(b)) reveals the presence of a ridge over the LMAQR. Such a synoptic pattern is associated with high surface temperatures, weak surface winds, a subsidence inversion, and relatively cloud free skies - conditions characteristically suited to the development of a lake breeze circulation along the EWI-Lake Michigan shore, and high levels of ozone in the LMAQR - produced at both the regional and sub-regional scales.

Laird et al. (2001) created composites of SLP and $10 \mathrm{~m}$ wind fields in the EUS for ES, WS, and BS lake breeze events (over the period 1982-96). Their composite of WS lake breeze events is remarkably similar to our SLP composite of exceedance-days. Their composite, like ours, features a ridge of high pressure that extends southeastward from WI and the LMAQR, to the southeastern USA. The west-southwesterly winds across EWI, as shown in Laird et al.'s (2001) composite of the $10 \mathrm{~m}$ wind field, is also in close agreement with the winds inferred from our SLP composite. The strong similarities between their composites and ours gives us confidence that our SLP composite does, in fact, represent a synoptic-scale pattern that is conducive to the development of a lake breeze circulation along the EWI-Lake Michigan shoreline.

Further, our SLP and $500 \mathrm{hPa}$ composites depict a synoptic-scale situation that is very similar to that present on the day Dye et al. (1995) conducted their case study of an ozone exceedance event in EWI - a day on which a lake breeze was present along the EWI shoreline, and the day upon which their conceptual model was based. ${ }^{2}$ Based on the above-mentioned similarities, we are thus quite confident that our composites are representative of the archetypal synoptic pattern that is conducive to the formation of a lake breeze circulation along the EWI-Lake Michigan shoreline.

As our composites show that the average state of the synoptic-scale atmosphere on exceedance-days was conducive to the formation of a lake breeze circulation along the EWI shoreline, this provides us with yet more evidence that the lake breeze is closely associated with exceedances of the $1 \mathrm{~h}$ ozone standard in EWI, and is likely a critical factor in determining where and when exceedances of the $1 \mathrm{~h}$ ozone standard will occur in EWI - a statement that is particularly true for the near-shore environment of EWI. 

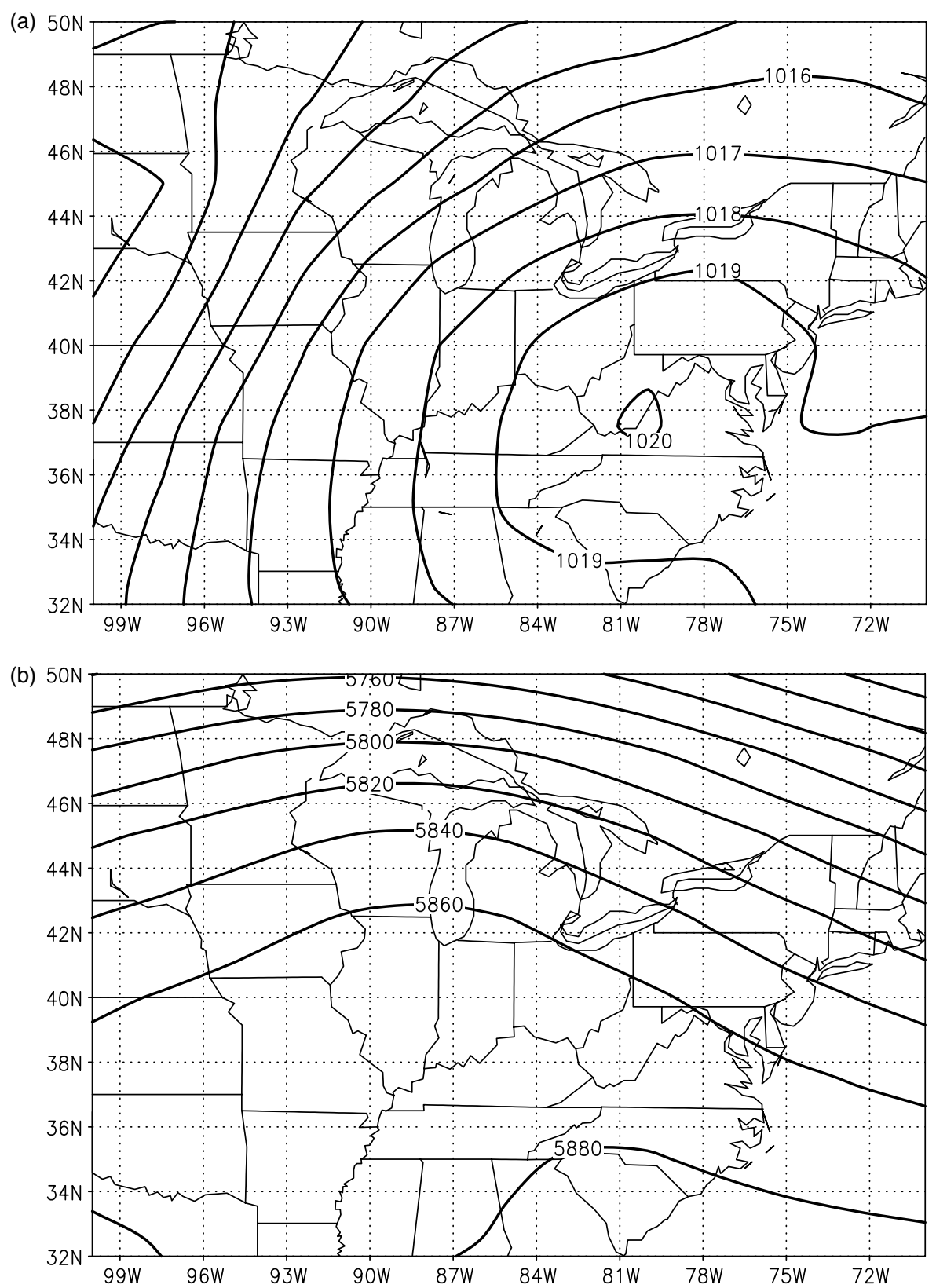

Figure 6. (a) SLP and (b) $500 \mathrm{hPa}$ height exceedance-day composites

\section{CONCLUSIONS}

Previous short-term investigations have revealed that the lake breeze circulation is connected with very high levels of ozone in EWI. Findings from one of the more recent research efforts of this type by Dye et al. (1995) led to the development of a generalized conceptual model of ozone transport in the LMAQR.

An important component of their model was the significant role that the lake breeze circulation plays in transporting ozone-rich air of the Lake Michigan conduction layer onshore to sites in EWI, resulting in levels of ozone in EWI that exceed the $1 \mathrm{~h}$ federal health standard. Short-term studies, like that of Dye et al. (1995), are limited, however, by the small number of cases examined. 


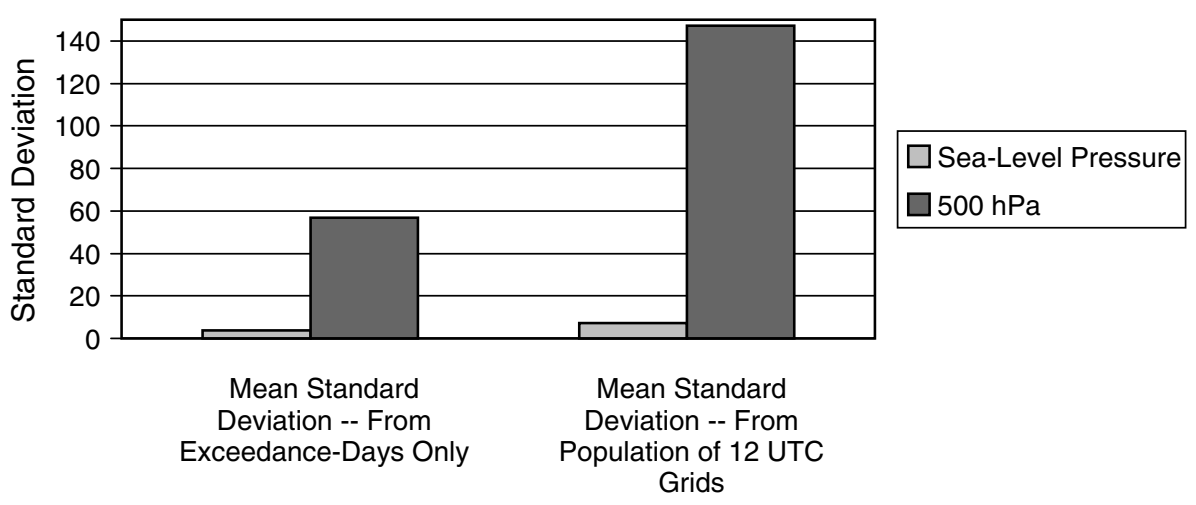

Figure 7. Means of gridded standard deviations for SLP and $500 \mathrm{hPa}$ height. Data using: (1) 12 UTC grids on exceedance-days during the period 10 May 1985-18 June 1994; (2) 12 UTC grids on all days over the same period

To gain a more accurate understanding of the role that the lake breeze plays in the ozone climate of EWI, we conducted a 15 year climatology of $1 \mathrm{~h}$ ozone exceedances in EWI. As part of the climatology, we analysed spatial and temporal patterns of $1 \mathrm{~h}$ ozone exceedances in EWI. Further, to gain a more accurate and complete understanding of the significance of the lake breeze-ozone exceedance relationship in the ozone climate in EWI, we used Laird et al.'s (2001) recently developed technique for discriminating lake breeze days to determine which and how many exceedance-days over the period of our climatology occurred in association with lake breezes. Our climatologically based investigation is particularly relevant given the fact that attainment status for locations is based on multiple years of ozone observations (for both the 1 and $8 \mathrm{~h}$ ozone standards).

The findings from our climatology reveal a decrease in both magnitude and frequency of exceedances of the $1 \mathrm{~h}$ ozone standard in EWI with increasing distance from the lakeshore. These findings are significant because they agree with findings from Dye et al.'s (1995) case study, which showed that near-lake sites had ozone readings with a greater magnitude than sites located farther inland.

Additionally, our findings revealed a positive correlation between average onset time of the initial exceedance-hour and a site's distance from the lakeshore. Our climatology also showed that monitoring sites in our study had a very high percentage of exceedance-days with initial exceedance-hours occurring in association with southeasterly flow; and at six of the eight stations in our study, three-quarters or more of such exceedance-days occurred in association with a lake breeze circulation - as determined from Laird et al.'s (2001) lake breeze identification methodology.

When Laird et al.'s (2001) method for identifying lake breeze days was applied to all exceedance-days at each of the respective monitoring stations, it was found that, at the near-shore sites, exceedances occurred in association with lake breezes, on average, $82.1 \%$ of the time. At the intermediate-distance stations, this figure was somewhat smaller: $58.3 \%$.

Further, our SLP and $500 \mathrm{hPa}$ composites showed that synoptic-scale conditions present on exceedance-days were conducive to the formation of lake breeze events in EWI; and when our SLP composite was compared with Laird et al.'s (2001) composites of SLP and $10 \mathrm{~m}$ winds on lake breeze days, excellent agreement in both the wind and pressure fields was observed.

Collectively, the above findings provide strong evidence, in a climatological context, that the lake breeze circulation is closely associated with the distribution of ozone in EWI in both space and time. More specifically, our results indicate that the lake breeze is a critical factor in determining where, when, and how large an exceedance will be at a particular location in EWI. Moreover, our results lead us to believe that the lake breeze circulation is directly associated with a significant proportion of the exceedances of the $1 \mathrm{~h}$ ozone standard in EWI - particularly at locations within $3 \mathrm{~km}$ of the lakeshore, and to a slightly lesser degree at sites located at distances ranging from approximately 8 to $30 \mathrm{~km}$ from the Lake Michigan shoreline. 
Thus, the lake breeze circulation not only affects ozone levels in EWI on the time scale of a few hours, as has been established by earlier researchers (e.g. Lyons and Cole, 1976; Dye et al., 1995), but, as our research has shown, the lake breeze is also an important factor in the long-term ozone climate of EWI. This finding is important, because multiple years of ozone observations are used to determine whether or not a community is in compliance with federal health standards for ozone.

Our findings are particularly significant in light of the US Supreme Court's 27 February 2001 decision upholding the EPA's authority to set health-protective ambient air standards, which in essence endorses the EPA's stricter, $80 \mathrm{ppb}$ ozone standard (US Government Documents, 2001). Mandated reductions in regional-scale $\mathrm{NO}_{x}$ by the US EPA (EPA, 1998b) will be useful in reducing the amount of air-mass ozone transported across the LMAQR's southern boundary; and these may be sufficient in themselves to allow 'inland' locations in EWI to meet the new $8 \mathrm{~h}, 80 \mathrm{ppb}$ health standard. However, because of sub-regionalscale transport processes in the LMAQR (in particular the onshore component of the lake breeze circulation), further reductions in VOCs and $\mathrm{NO}_{x}$ from sources within the LMAQR will be necessary if 'shoreline-located' sites in EWI are to meet the $1 \mathrm{~h}$ standard, let alone the stricter, $8 \mathrm{~h}$ standard in the future. Based on ozone data from 1997 to 1999, every county adjacent to Lake Michigan (from the Illinois border to the tip of the Kewaunee peninsula), violated the $8 \mathrm{~h}$ standard (EPA 2001). The fact that remote Door County, located in northeastern WI, along the lake and well away from any urban area, had twice as many days with high ozone as Milwaukee in $1999^{3}$ (Mardock et al., 1999) points out the significance of the sub-regional-scale ozone transport problem in the LMAQR. If shoreline locations in EWI are eventually to meet the $8 \mathrm{~h}$ ozone standard, and thus enjoy healthier air, more stringent measures to reduce $\mathrm{NO}_{x}$ and $\mathrm{VOC}$ emissions within the major metropolitan centres of the LMAQR will be necessary. More specifically, reductions will be required from within greater Milwaukee, Chicago, and Gary-Hammond, Indiana, all of which are significant source areas for ozone's precursors; and, on the basis of the Dye et al.'s (1995) conceptual model and findings from our ozone climatology, they have all been linked with episodes of high ozone along EWI's shoreline with Lake Michigan.

\section{NOTES}

1. As explained by Lyons and Cole (1973), the stable conduction layer above the lake surface - characteristically $50-200 \mathrm{~m}$ thick - forms when the air above the lake surface is cooled from below by Lake Michigan.

2. See also Hanna and Chang (1995) for a discussion of the synoptic-scale conditions present on this day.

3. Based on ozone data from 1 April 1999 to 25 July 1999.

\section{REFERENCES}

Altshuller AP. 1978. Association of oxidant episodes with warm stagnating anticyclones. Journal of the Air Pollution Control Association 28: $152-155$.

Biggs WG, Graves ME. 1962. A lake breeze index. Journal of Applied Meteorology 1: 474-480.

Burnett RT, Brook JR, Yung WT, Dales RE, Krewski D. 1997. Association between ozone and hospitalization for respiratory diseases in 16 Canadian cities. Environmental Research 72(1): 24-31.

Cody RP, Weisel CP, Birnbaum G, Lioy PJ. 1992. The effect of ozone associated with summertime photochemical smog on the frequency of asthma visits to hospital emergency departments. Environmental Research 58(2): 184-194.

Comrie AC, Yarnal B. 1992. Relationships between synoptic-scale atmospheric circulation and ozone concentrations in metropolitan Pittsburgh, Pennsylvania. Atmospheric Environment 26(3): 301-312.

Delfino RJ, Murphy-Moulton AM, Becklake MR. 1998. Emergency room visits for respiratory illnesses among the elderly in Montreal: association with low level ozone exposure. Environmental Research 76(2): 67-77.

Dye TS, Roberts PT, Korc ME. 1995. Observations of transport processes for ozone and ozone precursors during the 1991 Lake Michigan Ozone Study. Journal of Applied Meteorology 34: 1877-1889.

EPA, Office of Air Quality Planning and Standards. 1998a. Classifications of ozone nonattainment areas. URL: http://www.epa.gov/oar/oagps/greenbk/oyc.html. [Last accessed: 06/10/01.]

EPA, Office of Air Quality Planning and Standards. 1998b. Fact sheet, final rule for reducing regional transport of ground-level ozone. URL: http://www.epa.gov/ttn/oarpg/t1fs.html. [Last accessed: 06/10/01.]

EPA, Office of Air and Radiation. 2001. Ozone and carbon monoxide 1997-1999 air quality update. URL: http://www.epa.gov/oar/aqtrnd99/o3 coupdt.pdf. [Last accessed: 06/10/01.]

Guinnup D, Collom B. 1997a. Final report for the OTAG air quality analysis workgroup, volume II, summary and integration of results. URL: http://capita.wustl.edu/Otag/Reports/ExexSumm_5_8_97/Sum_vol2.html. [Last accessed: 06/10/01.]

Guinnup D, Collom B. 1997b. Telling the OTAG ozone story with data. URL: http://capita.wustl.edu/OTAG/Reports/AQAfinVol_I/ HTML/v1_exsum7.html. [Last accessed: 06/10/01.] 
Haney JL, Douglas SG, Chinkin LR, Souten DR, Burton CS, Roberts PT. 1989. Ozone air quality scoping study for the Lower Lake Michigan Air Quality Region. Tech. Rep. SYSAPP-89/101, System Application, Inc. [Available from Systems Application, Inc., 101 Lucas Valley Road, San Rafel, CA 94903.]

Hanna SR, Chang JC. 1995. Relations between meteorology and ozone in the Lake Michigan area. Journal of Applied Meteorology 34: $670-678$.

Hewson EW, Olsson LE. 1967. Lake effects on air pollution dispersion. Journal of the Air Pollution Control Association 17(11): 758-761.

Husar RB, Renard WP. 1997. Ozone as a function of local wind direction and wind speed - evidence of local and regional transport. URL: http://capita.wustl.edu/otag/Reports/OTAGWIND/OTAGWIND.html. [Last accessed 06/10/01.]

LADCO. 1995. Lake Michigan ozone study, Lake Michigan Ozone Control Program Project report, volume II, overview. Lake Michigan Air Directors Consortium. [Available from Lake Michigan Air Directors Consortium, 2350 E. Devon Ave., Suite 242, Des Plains, IL.]

Laird NF, Kristovich DAR, Liang XZ, Arritt RW, Labas K. 2001. Lake Michigan Lake breezes: climatology, local forcing, and synoptic environment. Journal of Applied Meteorology 40: 409-424.

Lennartson GJ, Schwartz MD. 1999. A synoptic climatology of surface-level ozone in eastern Wisconsin, USA. Climate Research 13(3): 207-220.

Lyons WA. 1972. The climatology and prediction of the Chicago lake breeze. Journal of Applied Meteorology 11: 1259-1270.

Lyons WA, Cole HS. 1973. Fumigation and plume trapping on the shores of Lake Michigan during stable onshore flow. Journal of Applied Meteorology 12: 494-510.

Lyons WA, Cole HS. 1976. Photochemical oxidant transport: mesoscale lake breeze and synoptic-scale aspects. Journal of Applied Meteorology 15: 733-743.

Lyons WA, Olsson LE. 1972. Mesoscale air pollution transport in the Chicago lake breeze. Journal of the Air Pollution Control Association 22(11): 876-881.

Mardock JE, Schneider C, Porreco G. 1999. No escape. Report, Clean Air Task Force and Clean Air Network. [Available from National Resources Defense Council, 1200 New York Avenue, NW, Suite 400, Washington, DC 20005.]

McKendry IG. 1994. Synoptic circulation and summertime ground-level ozone concentrations at Vancouver, British Columbia. Journal of Applied Meteorology 33: 627-641.

NCAR. 1996. General information and user's guide for the compact disc of the National Meteorological Center Grid Point Data Set, version III, Department of Atmospheric Sciences, University of Washington and the Data Support Section, NCAR. [Available from Mr Roy Jenne, Data Support Section, NCAR, PO Box 3000, Boulder, CO 80303.]

Oke TR. 1987. Boundary Layer Climates. Methuen.

Samson PH, Ragland KW. 1977. Ozone and visibility reduction in the midwest: evidence for large-scale transport. Journal of Applied Meteorology 16: 1101-1106.

Seinfeld JH. 1989. Urban air pollution: state of the science. Science 243: 745-752.

US Government Documents. 2001. Supreme Court Decision, Whitman v. American Trucking Associations, Inc. URL: http://www.supremecourtus.gov/opinions/00pdf/99-1257.pdf. [Last accessed 06/10/01.]

Vukovich FM, Fishman J. 1986. The climatology of summertime $\mathrm{O}_{3}$ and $\mathrm{SO}_{2}$ (1977-1981). Atmospheric Environment 20(12): $2423-2433$.

WI DNR. 1997. Wisconsin 1996 Air Quality Report. State of Wisconsin, Department of Natural Resources, Bureau of Air Management Vol. 22, PUBL-AM-221-97. [Available from State of Wisconsin, Department of Natural Resources, Bureau of Air Management, Box 7921, Madison, WI 53707.]

Williams TB. 1985. The climatic impact of Lake Michigan on air temperature in the southeast Wisconsin-northeast Illinois corridor. Ph.D. dissertation, University of Wisconsin-Milwaukee.

Wolff GT, Lioy PJ, Wight GD, Meyers RE, Cederwall RT. 1977. An investigation of long-range transport of ozone across the midwestern and eastern United States. Atmospheric Environment 11: 797-802.

Yarnal B. 1993. Synoptic Climatology in Environmental Analysis. Belhaven. 